\title{
Hubungan Rasio Trigliserida/High Density Lipoprotein-Cholesterol (TG/HDL-C) dengan Kejadian Infark Miokard Akut di RSUP Prof. Dr. R. D. Kandou Manado
}

\author{
Jaka K. Alia, ${ }^{1}$ Edmond L. Jim, ${ }^{2}$ Agnes L. Panda ${ }^{2}$ \\ ${ }^{1}$ Program Studi Pendidikan Dokter Fakultas Kedokteran Universitas Sam Ratulangi Manado \\ ${ }^{2}$ Bagian Kardiologi dan Kedokteran Vaskular Fakultas Kedokteran Universitas Sam \\ Ratulangi Manado \\ Email: jakaaliakurniawan@gmail.com
}

\begin{abstract}
Acute myocardial infarction (AMI) is caused by sudden disturbance of oxygen need and supply to the heart, affected by atheroma rupture that results in thrombocyte aggregation, thrombus formation, and coronary spasm that clogs the coronary artery. Patients that make it after a myocardial infarction have an increased risk of recurring infarctions with a yearly death number of 5\%, six times higher than people of the same age without coronary artery disease. This study was aimed to determine the correlation between triglyceride/high density lipoprotein-cholesterol and AMI incidence at Prof. Dr. R. D. Kandou Hospital, Manado. This was an analytical and observational study with a cross sectional and retrospective approaches. This study showed that mean TG/HDL-C ratio was higher in subjects with AMI than in subjects without AMI. The Pearson correlation test showed a p-value of 0.553 for the correlation between mean TG/HDL-C ratio and AMI incidence. In conclusion, there was no reltionship between mean TG/HDL-C ratio and acute myocardial infarction incidence.
\end{abstract}

Keywords: TG/HDL-C ratio, acute myocardial infarction, dyslipidemia

\begin{abstract}
Abstrak: Infark miokard akut (IMA) disebabkan oleh gangguan kebutuhan dan pasokan oksigen ke jantung secara mendadak disebabkan oleh ruptur ateroma yang berlanjut dengan agregasi trombosit, terbentuknya trombus, dan spasme koroner sehingga menyumbat arteri koroner. Pasien yang selamat dari infark miokard mengalami peningkatan risiko infark berulang dan memiliki tingkat kematian tahunan 5\%, enam kali lipat pada orang dengan usia yang sama dan tidak menderita penyakit jantung koroner. Penelitian ini bertujuan untuk mengetahui hubungan rasio trigliserida/kolesterol-HDL dengan kejadian infark miokard akut di RSUP Prof. Dr. R. D. Kandou Manado. Jenis penelitian ialah analitik observasional dengan desain potong lintang. Hasil penelitian mendapatkan bahwa rerata kadar rasio TG/HDL-C lebih tinggi pada subjek yang menderita IMA dibandingkan subjek non-IMA. Hasil uji korelasi Pearson terhadap hubungan antara rasio TG/HDL-C dengan kejadian IMA mendapatkan nilai $\mathrm{p}=0,553$. Simpulan penelitian ini ialah tidak terdapat hubungan antara rasio TG/HDL-C dengan kejadian infark miokard akut.
\end{abstract}

Kata kunci: rasio TG/HDL-C, infark miokard akut, dislipidemia

\section{PENDAHULUAN}

Infark miokard akut (IMA) merupakan salah satu penyakit yang paling sering ditemukan di dunia. Infark miokard akut adalah nekrosis jantung yang disebebkan oleh terganggunya kebutuhan dan pasoka oksigen ke jantung secara mendadak yang disebabkan oleh rupturnya ateroma yang berakibat lanjut agregasi trombosit, terbentuknya trombus, dan spasme koroner sehingga menyumbat arteri koroner. $^{1}$ Berdasar EKG 12-lead, IMA diklasifikasikan menjadi ST-segment elevation myocardial infarction (STEMI) dan non ST- 
segment elevation myocardial infarction (NSTEMI). Diagnosis STEMI ditegakkan jika terdapat keluhan angina pektoris akut disertai elevasi segmen ST yang persisten sedangkan diagnosis NSTEMI ditegakkan jika terdapat keluhan angina pektoris akut tanpa disertai elevasi segmen ST yang persisten. $^{2}$

Terdapat sekitar 32,4 juta kasus infark miokard dan stroke di seluruh dunia setiap tahunnya. Pasien yang selamat dari IMA mengalami peningkatan risiko infark berulang dan memiliki tingkat kematian tahunan 5\%, enam kali lipat pada orang dengan usia yang sama dan tidak menderita penyakit jantung koroner (PJK). ${ }^{3}$ Survey Sample Registration System (SRS) pada tahun 2014 di Indonesia menunjukkan PJK menjadi penyebab kematian tertinggi pada semua usia yakni sebesar $12,9 \%$. Menurut kelompok usia, PJK paling banyak terjadi pada kelompok usia 65-74 tahun (3,6\%), diikuti kelompok usia 75 tahun ke atas $(3,2 \%)$, kelompok usia 55-64 tahun $(2,1 \%)$, dan kelompok usia 35-44 tahun $(1,3 \%){ }^{4}$ Menurut hasil Riset Kesehatan Dasar (Riskesdas) tahun 2013, prevalensi infark miokard tertinggi yaitu di Sulawesi Tengah $(0,8 \%)$, diikuti Sulawesi Utara, DKI Jakarta, dan Aceh, masing-masing $(0,7 \%){ }^{5}$

Dislipidemia adalah kelainan metabolism lipid yang ditandai dengan peningkatan maupun penurunan fraksi lipid dalam plasma. Dislipidemia juga merupakan salah satu faktor aterosklerosis yang merupakan faktor risiko penting terjadinya penyakit jantung koroner. Trigliserida adalah salah satu jenis lemak yang terdapat dalam darah dan berbagai organ tubuh. Trigliserida yang tinggi dapat memicu terjadinya penebalan dinding pembuluh darah. High density lipoprotein-cholesterol (HDL-C) adalah lipoprotein yang mengandung banyak protein dan sedikit lemak, yang bertujuan untuk mengangkut kolesterol berlebih dari sel-sel dan jaringan-jaringan. Rendahnya HDL-C akan menunjukkan semakin kurangnya kolesterol berlebih yang diangkut kembali ke hati dan bisa membuat kolesterol mengendap pada dinding pembuluh darah. Penelitian yang dilakukan oleh Park et $\mathrm{al}^{6}$ yang mengamati rasio TG/HDL-C, rasio LDL-C/HDL-C, dan rasio TC/HDL-C menyimpulkan bahwa hanya rasio TG/HDL-C yang berhubungan dengan terjadinya stroke iskemik berulang. Sebuah hasil studi menyatakan bahwa rasio serum trigliserida dibagi kolesterol-HDL atau kolesterol-LDL memiliki nilai prognostik yang lebih baik untuk menilai risiko PJK dibanding pemeriksaan lipid sederhana. ${ }^{7}$

Semakin tinggi trigliserida dan semakin rendah HDL-C akan menghasilkan nilai yang semakin besar dan bisa menjadi prediktor kejadian infark miokard akut. Berdasarkan latar belakang yang telah diuraikan maka penulis ingin meneliti hubungan antara rasio TG/HDL-C dengan kejadian IMA di RSUP Prof. R. D. Kandou Manado.

\section{METODE PENELITIAN}

Jenis penelitian yang digunakan ialah analitik observational dengan desain potong lintang dan pendekatan retrospektif. Data penelitian diambil dari rekam medik penderita dengan diagnosis IMA dan diagnosis penyakit jantung dan pembuluh darah non IMA yang dirawat inap di Irina $F$ Jantung RSUP Prof. Dr. R. D. Kandou Manado.

Populasi penelitian yaitu seluruh data pasien IMA dan penyakit jantung dan pembuluh darah non IMA yang dirawat inap di Irina F Jantung RSUP Prof. Dr. R. D. Kandou Manado. Sampel penelitian diambil dari data populasi periode Januari 2019-September 2019 dengan rekam medik yang lengkap dan memenuhi kriteria inklusi.

Variabel penelitian yang digunakan meliputi rasio trigliserida/high density lipoprotein-cholesterol dengan kejadian IMA.

Penelitian ini telah mendapat persetujuan dari Komisi Etik Penelitian Kesehatan RSUP Prof. Dr. R. D. Kandou Manado, dengan nomor keterangan layak etik yaitu No. 104/EC/KEPK-KANDOU/XII/2019.

\section{HASIL PENELITIAN}

Berdasarkan hasil penelitian secara retrospektif yang telah dilakukan selama bulan Desember 2019 di Irina F Jantung 
RSUP Prof. Dr. R. D. Kandou Manado dan Instalasi Rekam Medik CVBC RSUP Prof. Dr. R. D. Kandou Manado didapatkan jumlah keseluruhan pasien 96 orang dengan usia 40-60 tahun. Tabel 1 memperlihatkan bahwa pasien yang berjenis kelamin lakilaki sebanyak 66 orang $(68,75 \%)$ dan perempuan sebanyak 30 orang $(31,25 \%)$.

Tabel 2 memperihatkan distribusi usia pasien ialah usia 40-50 tahun sebanyak 21 orang $(21,87 \%)$ dan usia 51-60 tahun sebanyak 75 orang $(78,13 \%)$.

Tabel 3 memperlihatkan bahwa rerata kadar trigliserida pada pasien IMA $(135,10+51,68 \mathrm{mg} / \mathrm{dL})$ lebih tinggi dibandingkan dengan pasien non-IMA $(126,96+$ 44,90 $\mathrm{mg} / \mathrm{dL}$ ) namun rerata kadar HDL pada pasien IMA $(38,58+15,95 \mathrm{mg} / \mathrm{dL})$ lebih rendah dibandingkan dengan pasien non-IMA $(43,69+32,08 \mathrm{mg} / \mathrm{dL})$. Rerata rasio $\mathrm{TG} / \mathrm{HDL}$ pada pasien IMA $(3,93+1,81 \mathrm{mg} / \mathrm{dL})$ lebih tinggi dibandingkan dengan pasien non-IMA $(3,70+1,95$ $\mathrm{mg} / \mathrm{dL}$ ).

Uji normalitas Saphiro-Wilk mendapatkan data terdistribusi normal karena nilai signifikansi >0,05 (untuk IMA $\mathrm{p}=0,423$, dan untuk non-IMA $\mathrm{p}=0,121$ ) sehingga dilanjutkan dengan uji korelasi Pearson (Tabel 4) yang mendapatkan nilai $r$ hitung =-0,061; hal ini menunjukkan bahwa rasio TG/HDL-C berhubungan secara negatif dengan kejadian IMA dan nilai $\mathrm{p}=0,553$ yang menunjukkan tidak terdapat korelasi bermakna antara rasio TG/HDL-C dengan kejadian IMA.

Tabel 1. Gambaran jenis penyakit pasien berdasarkan jenis kelamin

\begin{tabular}{ccccccc}
\hline \multirow{2}{*}{ Jenis kelamin } & \multicolumn{6}{c}{ Jenis penyakit } \\
& IMA & Non- & Jumlah & $(\%)$ \\
& STEMI & NSTEMI & IMA & & \\
\hline Laki-laki & 26 & 14 & 26 & 66 & $68,75 \%$ \\
Perempuan & 4 & 4 & 22 & 30 & $31,25 \%$ \\
Jumlah & & 48 & & 48 & 96 & $100 \%$ \\
\hline
\end{tabular}

Tabel 2. Gambaran jenis penyakit pasien berdasarkan usia

\begin{tabular}{|c|c|c|c|c|c|}
\hline \multirow{3}{*}{$\begin{array}{c}\text { Usia } \\
\text { (tahun) }\end{array}$} & \multicolumn{3}{|c|}{ Jenis penyakit } & \multirow[t]{3}{*}{ Jumlah } & \multirow[t]{3}{*}{$(\%)$} \\
\hline & \multicolumn{2}{|c|}{ IMA } & Non-IMA & & \\
\hline & STEMI & NSTEMI & & & \\
\hline $40-50$ & 5 & 3 & 13 & 21 & $21,87 \%$ \\
\hline $51-60$ & 25 & 15 & 35 & 75 & $78,13 \%$ \\
\hline Jumlah & \multicolumn{2}{|c|}{48} & 48 & 96 & $100 \%$ \\
\hline
\end{tabular}

Tabel 3. Gambaran kadar trigliserida, HDL, dan rasio TG/HDL pada pasien

\begin{tabular}{|c|c|c|c|c|c|c|c|}
\hline \multirow[b]{2}{*}{ Variabel } & \multicolumn{2}{|c|}{ Total $(n=96)$} & \multicolumn{2}{|c|}{ IMA $(n=48)$} & \multicolumn{2}{|c|}{ Non-IMA $(n=48)$} & \multirow[b]{2}{*}{$\begin{array}{c}\text { Nilai } \\
\mathbf{p}\end{array}$} \\
\hline & $\begin{array}{c}\text { Median } \\
\text { (min-maks) }\end{array}$ & $\begin{array}{c}\text { Mean } \\
+ \text { SD }\end{array}$ & $\begin{array}{c}\text { Median } \\
\text { (min-maks) }\end{array}$ & $\begin{array}{c}\text { Mean } \\
+ \text { SD }\end{array}$ & $\begin{array}{c}\text { Median } \\
\text { (min-maks) }\end{array}$ & $\begin{array}{c}\text { Mean } \\
+ \text { SD }\end{array}$ & \\
\hline $\begin{array}{c}\mathrm{TG} \\
(\mathrm{mg} / \mathrm{dL})\end{array}$ & $\begin{array}{c}121 \\
(42-303)\end{array}$ & $\begin{array}{l}131,03 \\
+48,33\end{array}$ & $\begin{array}{c}129 \\
(53-303)\end{array}$ & $\begin{array}{r}135,10 \\
+51,68\end{array}$ & $\begin{array}{c}117 \\
(42-228)\end{array}$ & $\begin{array}{r}126,96 \\
+44,90\end{array}$ & 0,498 \\
\hline $\begin{array}{c}\text { HDL } \\
(\mathrm{mg} / \mathrm{dL})\end{array}$ & $\begin{array}{c}35 \\
(14-217)\end{array}$ & $\begin{array}{c}41,14+ \\
25,33\end{array}$ & $\begin{array}{c}36 \\
(19-122)\end{array}$ & $\begin{array}{c}38,58+ \\
15,95\end{array}$ & $\begin{array}{c}35 \\
(14-217)\end{array}$ & $\begin{array}{c}43,69 \\
+32,08\end{array}$ & 0,849 \\
\hline $\begin{array}{c}\text { Rasio } \\
\text { TG/HDL }\end{array}$ & $\begin{array}{c}3,85 \\
(0,5-8,7)\end{array}$ & $\begin{array}{c}3,82+ \\
1,87\end{array}$ & $\begin{array}{c}4.0 \\
(0,8-8,7)\end{array}$ & $\begin{array}{c}3,93+ \\
1,81\end{array}$ & $\begin{array}{c}3,55 \\
(0,5-8,4)\end{array}$ & $\begin{array}{c}3,70 \\
+1,95\end{array}$ & 0,484 \\
\hline
\end{tabular}

$\mathrm{TG}=$ Trigliserida. $\mathrm{HDL}=$ High Density Lipoprotein . Rasio TG/HDL $=$ Rasio Trigliserida/High Density lipoprotein 


\section{BAHASAN}

Berdasarkan hasil penelitian secara retrospektif yang telah dilakukan di Irina $\mathrm{F}$ Jantung dan Rekam Medik CVBC RSUP Prof Dr. R. D. Kandou Manado didapatkan jumlah keseluruhan sebanyak 96 pasien dibagi atas pasien IMA dan non IMA masing-masing 48 pasien dengan usia 4060 tahun. Sebagian besar pasien berjebis kelamin laki-laki yaitu 66 orang $(68,75 \%)$.

Hasil penelitian menunjukkan bahwa rerata kadar trigliserida pada pasien IMA lebih tinggi daripada yang non-IMA; rerata kadar HDL pada pasien IMA lebih rendah daripada yang non-IMA; dan rerata rasio TG/HDL pada pasien IMA lebih tinggi daripada yang non-IMA walaupun tidak menunjukkan perbedaan yang bermakna. Hal ini disebabkan karena pasien IMA dan non-IMA memiliki rerata trigliserida dan HDL yang tidak jauh berbeda.

Uji korelasi yang dilakukan mendapatkan nilai $r=-0,61$ dan nilai $p=0,553$ yang menunjukkan bahwa walaupun kejadian IMA memiliki hubungan dengan rasio TG/HDL tetapi tidak terdapat hubungan bernakna antara kejadian IMA dengan rasio TG/HDL. Hal ini sejalan dengan penelitian yang dilakukan Chasani dan Santoso ${ }^{8}$ yang menyatakan tidak terdapat perbedaan profil lipid pada pasien IMA dan pasien penyakit jantung non-IMA. Hasil penelitian ini tidak sejalan dengan penelitian yang dilakukan Budiman et $\mathrm{al}^{9}$ yang menyimpulkan adanya peran dislipidemia, hipertensi, dan diabetes terhadap kejadian IMA.

Pada penelitian ini tidak didapatkan adanya hubungan antara kejadian IMA dengan rasio TG/HDL. Hal ini diduga karena pasien IMA dan non-IMA memiliki faktor perancu yang sama di antara penyakit penyerta yang memengaruhi profil lipid. Selain itu, terdapat kemungkinan adanya faktor lain yang memengaruhi hasil penelitian ini yaitu penggunaan obat-obatan yang dapat menurunkan kolesterol yaitu golongan obat lipid lowering agents. Terdapat lima golongan obat lipid lowering agents, yaitu golongan statin, fibrat, bile acid resins, ezetimibe, dan niacid.

Penelitian yang dilakukan Luz et $\mathrm{al}^{10}$ mengenai rasio TG/HDL sebagai prediktor PJK secara menyeluruh mendapatkan rasio TG/HDL sebagai indikator independen yang paling kuat untuk PJK menyeluruh dibanding pemeriksaan lipid lainnya.

\section{SIMPULAN}

Berdasarkan hasil penelitian ini dapat disimpulkan bahwa tidak terdapat hubungan bermakna antara rasio TG/HDL-C dengan kejadian infark miokard akut di RSUP Prof. Dr. R. D. Kandou Manado.

Pada penelitian selanjutnya, diharapkan peneliti tidak menggunakan subjek kontrol yang menderita penyakit jantung dan pembuluh darah untuk menghindari faktor perancu berupa penyakit penyerta yang sama dengan subjek. Juga diharapkan perubahan gaya hidup yang lebih baik dan pola konsumsi yang benar agar terhindar dari risiko hipertensi maupun IMA

\section{Konflik Kepentingan}

Penulis menyatakan tidak terdapat konflik kepentingan dalam studi ini.

\section{DAFTAR PUSTAKA}

1. Setianto BY, Rochmah W, Nurohman A. Hubungan angka leukosit pada infark miokard akut dengan kejadian cardiac event selama dirawat di rumah sakit. Berkala Ilmu Kedokteran. 2003;35(1):32.

2. Irmalita, Juzar AD, Andrianto, penyusun. Pedoman Tatalaksana Sindrom Koroner Akut (3rd ed). Jakarta: Centra Communications, 2014; p. 3-4.

3. Prevention of Recurrences of Myocardial Infarction and Stroke Study. World Health Organization. [cited 2019 Aug 26].

4. Penyakit jantung penyebab kematian tertinggi, Kemenkes ingatkan CERDIK. Jakarta: Kementerian Kesehatan Republik Indonesia. Biro Komunikasi dan Pelayanan Masyarakat; 2017 July 29 [cited 2019 Aug 26].

5. Riset Kesehatan Dasar 2013. Kementerian Kesehatan Republik Indonesia, 2013 [cited 2019 Aug 26].

6. Park JH, Lee J, Ovbiagele B. Nontra- 
18 Medical Scope Journal (MSJ), Volume 1, Nomor 2, Januari-Juni 2020, hlm.14-18

ditional serum lipid variables and recurrent stroke risk. Stroke. 2014;45 (11):3269-74.

7. Manninen V, Tenkanen L, Koskinen P, Huttunen JK, Manttari M, Heinonen $\mathrm{OP}$, et al. Joint effects of serum triglyceride and LDL cholesterol and HDL cholesterol concentrations on coronary heart disease risk in the Helsinki Heart Study. Implications for treatment. Circulation. 1992; 85(1):37-45.

8. Alexander BS, Chasani S, Santoso. Perbedaan profil lipid pada pasien infark miokard akut dan penyakit jantung non infark miokard akut. Jurnal Media Medika Muda. 2013;2(1).

9. Budiman B, Sihombing R, Pradina P. Hubungan dislipidemia, hipertensi dan diabetes melitus dengan kejadian infark miokard akut. Jurnal Kesehatan Masyarakat Andalas. 2017;10(1):32-7.

10. Luz PL, Favarato D, Faria-Neto Junior JR, Lemos P, Chagas AC. High ratio of triglycerides to HDL-cholesterol predicts extensive coronary disease. Clinics. 2008;63(4):427-32. 